\title{
The Concept of Family in the Selected Novels from the Emerging Countries: A Sociological Analysis
}

\author{
By Juanito O. Cabanias*
}

This paper determined the concept of family from a sociological perspective, as reflected in the selected novels from the emerging countries. This also presented the sociological factors (i.e. cultural, economic and political) relating to the concept of family in the selected novels, the concept of family drawn in the selected novels from the emerging countries under study and the similarities and/or differences in the concept of family the authors of the selected novels show in their respective works. The Expanded Sociological Analysis (ESA) was used to explore the cultural, political and economic aspects of the novels supported by Marxist Literary Criticism particularly the following models: Lukacs' The Reflection Model, Lucien Goldmann's The Genetic Model and Epifanio San Juan's The Society and Critical Theory. The data used in this study were primarily the texts of the six (6) novels from the emerging countries. The analyses of the six (6) selected novels from the emerging countries revealed the following concepts of family: to protect the image of the family, the Egyptian parents (Kamel Efendi and Samira) portray and exercise the patriarchal matriarchal egalitarian rule over their children in The Beginning and the End, as the Columbian parents (Jose Arcadio Buendia and Ursula Iguaran Buendia) in One Hundred Years of Solitude do. However, the Vietnamese mother imposes the matriarchal rule in the Paradise of the Blind and the heroines (Mama Elena) in Like Water for Chocolate, and (Emy) in Mass. By contrast, the Jamaican father (Winston) in The Family solely over practices the patriarchal rule. A Close Mini-Society where all the members of the family try to live together in times of happiness and sadness is apparent in Mahfouz's and Sionil Jose's novels. One very important concept of family revealed in the mother's authority figure is seen in Mahfouz's novel (in the absence of Kamel Efendi) and in Thu Huong's as well as in Esquivel's work, including Sionil Jose's strong woman character, clearly seen is the multitude of social bonds based on consanguinity rather than on household among family members, be it in the novels of Mahfouz, Garcia Marquez, Thu Huong, Esquivel, Emecheta, and Sionil Jose. The social concept of family where every member lives together and does things together like solving problems and contributing to a peaceful environment, stands out very clearly in the works of the men and women novelists under study. Lastly, the voluntary association concept that is, spouses can leave, children have outside resources to rely on if they perceive the family crumbling, is markedly present in Emecheta's The Family.

Keywords: Concept of family, Emerging countries, Literatures reflecting society, Novels, Sociological Analysis

\section{Introduction}

\section{The Meaning of Family}

Alas! Families born unto the modern age

Unconventional, yet their feelings bestow

Deepest bonds from those---

Which were allowed to choose

Genetics play no role and thus

Love surges through the veins

Often times thicker than that---

Found amongst distributed blood

\footnotetext{
* Juanito O. Cabanias, Vice Chancellor for Academics, De La Salle Health Sciences Institute, Philippines.
} 


\author{
Savor now what you do own \\ Laugh and cry with those drawn near \\ The chosen who do reciprocate--- \\ Mere simple friends be they naught \\ Luckiest are the enlightened souls \\ Open and free to attain such wealth \\ A meaning sadly shrouded from many--- \\ True family formed with hand-picked hearts. \\ Anonymous
}

The poem says that family, which centers on love, is more valuable than all the things in the world. In these fast changing and unpredictable times, where everything may happen in just the wink of an eye, where fate may equally begin and end by a mere touch, love is never and can never be spared. Many try to raise a family but fail because, though love emits a flame that keeps the fire of relationship burning, or even conquers all and surmounts even the insurmountable odds, only few selected ones conquer love. Only a selected few whose love goes beyond human understanding survive. Undeniably, family is born out of unconditional love a person can truly and voluntarily give.

Many stories, e.g. fairy tales or fantastic stories, plays, poems, and other literary pieces deal with or feature families. To cite some, from the children's favorite tales such as "Cinderella", "Hansel and Gretel", "Sleeping Beauty", the Filipinos' favorite Awits "Ibong Adarna" and "Florante at Laura", Aguilar's famous song "Anak", Shi-Fu's "The Romance of the West Chamber", Shakespeare's "Hamlet" and "Romeo and Juliet", Sophocles' "Antigone" and "Oedipus Rex", Chekov's "Cherry Orchard" and "Three Sisters", Guerrero's "The Forsaken House", to the critically acclaimed novel Anna Karenina (1875) of Tolstoy, Tuvera's Hand of the Enemy (1962), Sionil Jose's The Pretenders (1962), and Morrison's Song of Solomon (1978), they feature the family as either the central focus or the theme of the story. The reason probably for its popularity being is that the family emerges as the first and perhaps the most enduring context for growth (Whyte 1987). The family also serves as a primary agent for socialization because it provides a major context for adjustment. Furthermore, it is in the universal theme of family perhaps where all literary pieces begin and end their wonderful area of exploration.

The family is generally regarded as a major social institution and a locus of much of a person's social activity. It is a social unit created by blood, marriage, or adoption, and can be described as nuclear (parents and children) or extended (encompassing other relatives) (Nam 2004).

While emphasizing different organizing principles, for example, quality of personal relationships, social functions and legal prescriptions, the definition reveals a certain identity; it specifies a conceptual group for analytical purposes, in order to derive generalizations about the institutional character of the family (Nam 2004: 2).

Indeed, theoretical literature on the family has emerged in a wide range of academic disciplines. However, there is little consensus in these writings on what really the concept of family is. It is observed that the sociological treatises 
in the family begin with a basic definition of what a family is. The technical usages in these definitions vary greatly, in focusing on different conceptual features, and expressing different levels of specificity or abstraction.

With all these observations and considerations, the researcher found it very interesting and challenging to investigate the concept of family in the novels from the emerging countries. No research undertakings have been conducted yet regarding the concept of family from the emerging countries, as reflected in their literature. As the study dwelled into the heart of its investigation, it sought to determine the sociological factors relating to the concept of family and to uncover the similarities and differences of the novelists' concept of family in their respective works. And for a better understanding and analysis of the texts used in this study, a sociological analysis was applied.

The Sociological Analysis considers literature as principally the expression of man within a given social institution. Often, this social institution is reduced to a question of economics, in which men are somewhat simplistically divided into haves and have-nots, thus using the proletarian approach, which underscores the conflict between the two classes. The Sociological Approach stresses social relevance, social commitment, contemporaneity, and deems communication with the reader important. Wanting to disseminate a message especially when it tends subtly or deliberately towards propaganda, the selection has to be understood. Socially-committed literature almost deliberately invites questions using this approach (Maramba 1993).

According to Blau and Meyer (1971), a central concern of sociologists is the analysis of social structure whether it is the structure of small groups like the families, organizations, communities, or whole societies. In the process of analyzing these, the social scientists consider the common values and beliefs that people hold part of the social structure, while others restrict the term to the patterns of relations among individuals, groups, and collectivities (for example the class structure or the kinship system) distinguishing social structure in this narrower sense from the normative order consisting of common values and beliefs concerning conduct.

In support of the statements explicated by Blau and Meyer, the analysis of the novels focused first on the cultural aspect. The sociological framework attempted to explore the relationship of the members to each other. This direction then led to issues surrounding the sense of affection displayed toward the children in the parent-child relationship, and even with the extended family members. It discussed also how society and family changed with the times as much as the roles performed by the different members of the family.

The final exploration focused on the economic and political aspects, and viewed from a more contemporary point of reference; namely: the effects of some forces upon families (economic status, war, prejudice, changing values, change of government, technology, etc.) which either weakened and pulled families apart or strengthened and solidified them (Marshall and Huff 1986).

Finally, it is emphasized that the present study departed itself from mere critiquing and analysis along sociological perspectives. This study stressed how it differs from the studies and researches conducted by the aforementioned 
authorities. The selected novels written by the world's most brilliant novelists were subjected to the sociological analysis expounded by Kennedy and Gioia (2003) through the incorporation of the Marxist Literary Criticism.

\section{Objectives of the Study}

This study focused on the concept of family from the sociological perspective, as reflected in the selected novels from the emerging countries. Specifically, it highlighted the following:

- Sociological factors (i.e. cultural, economic and political) relating to the concept of family and vice versa are presented in the selected novels;

- Concept of family drawn in the selected novels from the emerging countries under study, and

- Similarities and/or differences in the concept of family the authors of the selected novels show in their respective works.

\section{Theoretical Framework}

Sociological Analysis focuses on the relationship between literature and society. Literature is always produced in a social context. Writers may affirm or criticize the values of the society in which they live, but they write for an audience and that audience is society. Through the ages the writer has performed the functions of priest, prophet, and entertainer: all of these are important social roles. The social function of literature is the domain of the sociological critic ${ }^{1}$. Even works of literature that do not deal overtly with social issues may have social issues as subtexts. The sociological critic is interested not only in the stated themes of literature, but also in its latent themes. Like the historical critic, the sociological critic attempts to understand the writer's environment as an important element in the writer's work. Like the moral critic, the sociological critic usually has certain values by which he or she judges a literary work ${ }^{2}$.

Sociological Criticism, then, reflects the way literature interacts with society. Sociological critics show how literature can function both as a mirror that reflects social realities and as a lamp that inspires social ideals.

Akin to this stance, Kennedy and Gioia (2003) explain also that Sociological Criticism basically "examines literature in the cultural, economic and political context in which it is written or received", exploring the relationships between the artist and society. Sometimes, it examines the artist's society to better grasp the author's literary works; other times, it may examine the representation of such societal elements within the literature itself. One influential type of Sociological Criticism, Marxist Criticism, focuses on the economic and political elements of art, often emphasizing the ideological content of literature. Because Marxist Criticism often argues that all art is political, either challenging or endorsing (by

\footnotetext{
${ }^{1}$ Retrieved from goo.gl/aKxS3x. [Accessed: 13 April 2017]

${ }^{2}$ Retrieved from goo.gl/aKxS3x. [Accessed: 13 April 2017]
} 
silence) the status quo, it is frequently evaluative and judgmental, a tendency that "can lead to reductive judgment". Nonetheless, Marxist Criticism "can illuminate political and economic dimensions of literature which other approaches overlook".

In presenting the analyses of the texts used in the study, the Marxist Literary Criticism was used in interpreting the theme and the concept of family.

\section{Marxist Literary Criticism}

One of the most important forms of Sociological Criticism is Marxist Criticism. Karl Marx (1818-1883) developed a theory of society, politics, and economics called dialectical materialism. Writing in the nineteenth century, Marx criticized the exploitation of the working classes, or proletariat, by the capitalist classes who owned the mines, factories and other resources of the national economies. Marx believed that history was the story of class struggles and the goal of history was a classless society in which all people would share the wealth equally. This classless society could only come about as a result of a revolution that would overflow the capitalist domination of the economy (Lund as cited in Literary Criticism Primer n.d.).

Central to Marx's understanding of society is the concept of ideology. As an economic determinist, Marx thinks that the system of production was the most basic fact in social life. Workers created the value of manufactured goods, but owners of the factories reaped most of the economic rewards. In order to justify and rationalize this inequity, a system of understandings or ideology was created, for the most part unconsciously. Capitalists justified their taking the lion's share of the rewards by presenting themselves as better people, more intelligent, more refined, and more ethical than the workers. Since literature is consumed, for the most part, by the middle classes, it tends to support capitalist ideology, at least in countries where that ideology is dominant (Lund as cited in Literary Criticism Primer n.d.: 2). For a more comprehensive and detailed presentation of the Marxist Literary Criticism, the following models were used in the discussion and analysis of the novels.

\section{George Lukacs' The Reflection Model}

Lukacs treats literary works as reflections of an unfolding system. A realist work must reveal the underlying pattern of contradictions in a social order. His view is Marxist in its insistence on the material and historical nature of the structure of society. To "reflect" is to "frame a mental structure" transposed into words. A novel, for example, "reflects reality, not by rendering its mere surface appearance, but by giving a truer, more complete, more vivid, and more dynamic reflection of reality" (Selden 1997).

Lukacs rejects a mere "photographic" representation of reality. He says that a truly realistic work gives a sense of the artistic necessity of the images presented; they possess an "intensive totality" which corresponds to the "extensive totality" of the world itself (Selden 1997).

Furthermore, for Lukacs, a novel, for that matter, must be assessed to determine its effectiveness on its ability to reflect the historical and material 
conditions of society; these are the main criteria for assessing its realism (Webster 1996). It can be observed that Lukacs is very much concerned in presenting characters that are a part of a total social and historical fabric even though his emphasis might appear to be anti-individual. In his work The Historical Novel (1937), he says that the novel is not just the reflection of history's loss of an earlier social cohesion but an interpretation of social values. In showing how social values are embedded in social practices, he proves that literature can interpret society as well as mirror it. The best novels not only reflect the ideas that bind a society together but they are also socially constructive. The novelist creates literary forms that will have an effect on social life (Walhout and Ryken 1991).

\section{Lucien Goldmann's The Genetic Model}

Goldmann rejected the idea that texts are creations of individual genius and argued that they are leased upon the mental structures belonging to particular groups or classes. These "worldviews" are perpetually constructed and dissolved by social groups as they adjust their mental image of the world in response to the changing reality before them (Selden 1997).

The expressive relationship between social class and literary text is registered not in "reflected" content but in a parallelism of form or "homology". Goldmann's alternative to correlating the literary work with the author's life and personality was not to focus on the text but to draw out the "mental structure" of the author's social group (Selden 1997). The literary work is the expression not of the author's self but of the social class of which the author is a member. Literary works consequently become in a sense, for Goldmann, collective products of social groups. A great writer is one who elaborates the mental structure of the group so that his or her work could relay back to the group a sharpened awareness of that structure (Selden 1997: 104).

Lucien Goldmann in The Hidden God (1964) has argued that more than any other kind of activity, literature is capable of expressing a "world vision" which links together the members of a social group (a group which, in most cases, assumes the existence of a social class) and which opposes them to members of other social groups.

Goldmann, a disciple of Lukacs, attempts to understand why literary works that seem to rise above the societies, which mirror societies most realistically, are often considered mediocre from an aesthetic point of view. He answers these questions with his own theory of genetic structuralism. The great author assimilates into his art cultural values that are implicit in a society, but are not always consciously recognized by those who live in it. This ability to reflect the underlying values of society is what gives scope to the works of great writers and makes them aesthetically valuable beyond their own age. The great artist sees how various aspects of social life are interrelated and thus stands apart from as well as within his or her culture (Walhout and Ryken 1991).

Furthermore, Walhout and Ryken (1991: 76) add that great works of art have aesthetic values that last beyond their own time because they capture a vision of the society as a whole as well as depict particular images of social life that the artist takes directly from society. Mediocre artists render their societies 
vividly, but not with the interpretive vision of the great artists. Thus, although literature has its genesis in social life, the critic must analyze the structural and aesthetic qualities of literature as well as its specific content in order to see how the social value of literature extends beyond its particular place of origin.

\section{Epifanio San Juan's The Society and Critical Theory}

In general, to San Juan (1990), sociology as a discipline emerges from the increasing fragmentation and atomization of the industrial capitalist society. In trying to solve the problem of working-class unrest, sociologists repudiated Marxism and its totalizing mode in favor of the nineteenth century positivism constituted by an empirical-technological ethos and the social-Darwinist extrapolations from the biological sciences. The Italian thinker Antonio Gramsci's description of sociology's genealogy sums up its limits: "Sociology has been an attempt to create a method for historico-politico science, dependent on an already elaborated philosophical system". Sociology is, therefore, an attempt to deduce experimentally the laws of the evolution of human society.

In elucidating the foundations of Sociological Criticism and the complex transactions of literature and society, San Juan believes that critics differ in their definition of society. And what differentiates the Marxist from Sociological Strategies hinges on its historical/dialectical mode of inquiry. What is distinctive in Marx's conception of society is that it posits the indivisibility of the human and the social. It rejects the antithesis of society and the individual linked only by a hypothetical social contract nor is society cognized as a supra-individual phenomenon. Marx (1844) reiterates in his Economic and Philosophical Manuscripts:

"Even when I carry out scientific work ... I perform a social, because human, acts. It is not only the material of my activity-like the language itself which the thinker uses-which is given to me as a social product. My own existence is a social activity ... The individual is a social being."

For Marx (1844), human existence is essentially praxis, labor-the dialectical interplay of consciousness and the material surroundings. Society is in nature; humans are part of the natural world, the material/setting for all activities. Since the production and reproduction of life, through work and procreation, are simultaneously a social and natural relationship, the economic processes cannot be divorced from those relations. Karl Korsch (1923) thus asserted that Marx's science of society is not sociology, but political economy.

San Juan (1990) further discusses that the fundamental principle of Marx's theory is the historical transformation of society: the interaction between society and nature develops in time through collective labor. This historical interaction climaxing in class struggles and revolution engenders and transforms relations among humans. Manifested in various levels of contradictions and conflicts, the historical process which constitutes different stages or types of societies presents two (2) aspects: the development of productive forces and the changing social division of labor within the production relations. What defines the type of social 
formation depends on the modes of production (the level of development of productive forces and the corresponding production relations) and the ideological and the political practices in it.

In the 1859 "Preface" to A Contribution to the Critique of Political Economy, Marx states that the relations of production serve as the foundation on which "rises a legal and political superstructure and to which corresponds definite forms of social consciousness". The mode of the production of material life conditions the social, political and intellectual life processes in general.

Figure 1 illustrates the conceptual paradigm used in this study. The texts (selected novels from the emerging countries) are placed first in the diagram because all approaches must deal, to some extent or another, with the text themselves. The Expanded Sociological Analysis (ESA) (approaches and theories) is the main component in determining the concept, as reflected in the novels. In the process of determining the concept of family, which was supported by the sociological interpretations, the texts were examined along the cultural, economic and political dimensions/contexts in which they are written or received, "exploring the relationships between the artist and the society" (Kennedy and Gioia 2003). Moreover, the Sociological Criticism examines literature in the light of social groups, relationships and values. Accordingly, it also emphasizes the nature and effect of the social forces that shape power relationships between groups or classes of people.

Moreover, the Expanded Sociological Analysis (ESA) complements with the Marxist Literary Criticism, which focuses on the following models: Lukacs' The Reflection Model which says to "reflect" is to "frame a mental structure" transposed into words. A novel, for example, "reflects reality, not by rendering its mere surface appearance, but by giving a truer, more complete, more vivid, and more dynamic reflection of reality", Goldmann's The Genetic Model which explains that the literary work is the expression not of the author's self but of the social class to which the author belongs. Literary works consequently became in a sense, for Goldmann, collective products of social groups and San Juan's The Society and Critical Theory which points out that the fundamental principle of Marx's theory is the historical transformation of society: the interaction between society and nature develops in time through collective labor.

The aforementioned models were used to be able to ferret out if there are changes, similarities and differences in the concept of family in the novels analyzed. This study focused on six (6) selected novels from the emerging countries written by some of the world's brilliant novelists: Naguib Mahfouz's The Beginning and the End (1949); Gabriel Garcia Marquez's One Hundred Years of Solitude (1967); Duong Thu Huong's Paradise of the Blind (1988); Laura Esquivel's Like Water for Chocolate (1989); Buchi Emecheta's The Family (1990), and F. Sionil Jose's Mass (1990). The abovementioned texts are all in English translated versions, except Buchi Emecheta's The Family and F. Sionil Jose's Mass, which were originally written in English. The study was limited to a sociological interpretation, as expounded by Kennedy and Gioia (2003) of the theme and concept of family with supporting ideas from the Marxist Literary Criticism. 
Figure 1. Conceptual Paradigm

\begin{tabular}{|l|l|}
\hline $\begin{array}{l}\text { SELECTED NOVELS FROM THE } \\
\text { EMERGING COUNTRIES }\end{array}$ \\
- Mahfouz (1949) The Beginning and the End \\
- Garcia Marquez (1967) One Hundred Years \\
of Solitude \\
- Thu Huong (1988) Paradise of the Blind \\
- Esquivel (1989) Like Water for Chocolate \\
- Emecheta (1990) The Family \\
- Sionil Jose (1990) Mass
\end{tabular}


The model for sociological analysis was expanded to include Marxist Literary Theories; namely: Lukacs' The Reflection Model, Goldmann's The Genetic Model and San Juan's The Society and Critical Theory.

In discussing and in presenting the analyses of the texts, the researcher employed the Expanded Sociological Analysis (ESA) Model. The presentation of the concept of family focused on the cultural, economic and political aspects, after which a comparative analysis was done to highlight the commonalities and differences of the concept of family in the six (6) novels. For a better understanding of the study, the following terms are hereby defined:

\section{Concept of Family}

This phrase explicates whether a family is perceived to be social where a family lives together and the family does things together like solving problems and making a peaceful environment. It also emphasizes love, compassion and respect for each other. As emphasized in the Ethiopian culture, a family is not only a house, but a close, mini-society in which every member shares in the responsibilities in times of sadness and in times of happiness (Johnson 1971). This phrase could also mean multitude of social bonds, it is based mostly on consanguinity than on household (Krekula 2002). On the other hand, family could be conceptualized as patriarchal, the father in charge, the mother in a subordinate or matriarchal role, as an arbiter in attempting to maintain family harmony and a conciliator. From another perspective, the conception of family could focus on an authority figure regardless of the sex or relation of the person who is the authority figure. Furthermore, according to Schwartz (2005), one concept of family is the voluntary association where spouses can leave and children have outside resources to rely on if they perceive the family crumbling.

\section{Emerging Countries}

Generally, these are the countries which are not as industrialized or technologically and economically advanced as compared to the first world countries. They are Mexico, Egypt, Colombia, Nigeria and other countries under the African continent, Philippines, Vietnam, Haiti, Dominican Republic, etc.

\section{Expanded Sociological Analysis (ESA)}

As the main approach used in determining the concept of family in the selected novels from the emerging countries, it examines the works along the cultural, economic and political dimensions/contexts. In the presentation of the analyses of the texts, the ESA was used with the Marxist Literary Criticism supported by the different models of Lukacs, Goldmann and San Juan.

\section{Genetic Model}

Goldmann questions the idea that texts are creations of individual genius rather than based upon "trans-individual mental structures" belonging to particular groups (Selden 1997: 104). 


\section{Intra-textual Meaning}

The meaning, which originates not within a work itself, but which originates in a related work in a larger collection (Harris 1997 as cited by Chandler 2014).

\section{Reflection Model}

The use of the term "reflection" is characteristic of Lukacs' work as a whole. Rejecting the "naturalism" of the then recent European novel, he returns to the old realist view that the novel reflects reality, not by rendering its mere surface appearance but by giving a "truer", "more complete", "more vivid" and "more dynamic" reflection of reality (Selden 1997).

\section{Society and Critical Theory}

San Juan (1990) points out that the fundamental principle of Marx's theory is the historical transformation of society: the interaction between society and nature develops in time through collective labor.

\section{Methodology}

Generally, this study used a sociological framework as the basis for the discussion of the concept of family. The Expanded Sociological Analysis (ESA) explored on the cultural, political and economic aspects supported by Marxist Literary Criticism.

\section{Procedure}

The procedure was divided into four phases:

- Phase I- Reading and Selection of Novels.

- Phase II- Drawing up the Criteria for the Preparation of the Final List of Novels.

- Phase III- Coming up with Final List of Novels Selected in the Study.

- Phase IV- Presenting the Expanded Sociological Analysis of each Novel.

Each phase is described below.

Phase I- Reading and Selection of the Preliminary List of Novels

These novels had been drawn from: Russian Fiction, Philippine Literature in English, Latin-American Literature, African Literature, Asian Literature, Contemporary British-American Literature, Sociology of Literature, and the like. Tentatively some twenty (20) novels representing the different continents were considered (Table 1). 
Table1. Preliminary List of Novels

\begin{tabular}{|c|c|c|c|c|}
\hline & Title & Author & $\begin{array}{c}\text { Country of } \\
\text { Origin }\end{array}$ & $\begin{array}{c}\text { Date } \\
\text { Published }\end{array}$ \\
\hline 1. & Anna Karenina & Leo Tolstoy & Russia & 1875 \\
\hline 2. & $\begin{array}{l}\text { The House by the Medlar } \\
\text { Tree }\end{array}$ & Giovanni Verga & Italy & 1881 \\
\hline 3. & Buddenbrooks & Thomas Mann & Germany & 1902 \\
\hline 4. & Reeds in the Wind & Grazia Deledda & Italy & 1913 \\
\hline 5. & The Good Earth & Pearl Buck & USA & 1931 \\
\hline 6. & The Grapes of Wrath & John Steinbeck & USA & 1939 \\
\hline 7. & The Beginning and the End & Naguib Mahfouz & Egypt & 1949 \\
\hline 8. & The Family Moskat & Isaac Bashevis & Poland & 1950 \\
\hline 9. & The Makioka Sisters & Junichiro Tanizaki & Japan & 1957 \\
\hline 10. & $\begin{array}{l}\text { Sampaguitang Walang } \\
\text { Bango }\end{array}$ & Iñigo Ed Regalado & Philippines & 1959 \\
\hline 11. & The Hand of the Enemy & $\begin{array}{l}\text { Kerima Polotan- } \\
\text { Tuvera }\end{array}$ & Philippines & 1962 \\
\hline 12. & $\begin{array}{l}\text { The Family of Pascual } \\
\text { Duarte }\end{array}$ & Camilo Jose Cela & Spain & 1964 \\
\hline 13. & $\begin{array}{l}\text { One Hundred Years of } \\
\text { Solitude }\end{array}$ & $\begin{array}{c}\text { Gabriel Garcia } \\
\text { Marquez }\end{array}$ & Colombia & 1967 \\
\hline 14. & Family & Pa Chin & China & 1972 \\
\hline 15. & The Great Ponds & Elechi Amadi & Nigeria & 1973 \\
\hline 16. & Song of Solomon & Toni Morisson & USA & 1977 \\
\hline 17. & Paradise of the Blind & Duong Thu Huong & Vietnam & 1988 \\
\hline 18. & Like Water for Chocolate & Laura Esquivel & Mexico & 1989 \\
\hline 19. & Mass & F. Sionil Jose & Philippines & 1990 \\
\hline 20. & The Family & Buchi Emecheta & Nigeria & 1990 \\
\hline
\end{tabular}

Phase II- Drawing up the Criteria for the Preparation of the Final List of Novels

Out of the novels presented, only six (6) novels representing only the emerging countries were used instead guided by the following criteria: (1) the novels must be written by writers from the emerging countries (e.g. Mexico, Egypt, Colombia, Africa, Philippines, Vietnam, Haiti, Dominican Republic, etc.); (2) the novels should all be written in English or English Translated Versions; (3) the novels must exhibit high distinct literary merit/quality according to the standards of the literature experts in selected Universities; (4) the novels must show universality of thematic appeal; and (5) men and women novelists must have equal representation.

Phase III- Coming up with Final List of Novels Selected in the Study

After the preparation of the criteria, the researcher strictly adhered to them in the choice of the six (6) novels from the emerging countries, as shown in Table 2. 
Table 2. Final List of Novels Selected in the Study

\begin{tabular}{|l|l|c|c|c|c|}
\hline Continent & \multicolumn{1}{|c|}{ Title } & Novelist & Gender & $\begin{array}{c}\text { Country of } \\
\text { Origin }\end{array}$ & $\begin{array}{c}\text { Date } \\
\text { Published }\end{array}$ \\
\hline Asia & $\begin{array}{l}\text { 1. Paradise of the Blind } \\
\text { 2. Mass }\end{array}$ & $\begin{array}{c}\text { Thu Huong } \\
\text { Sionil Jose }\end{array}$ & $\begin{array}{c}\text { Woman } \\
\text { Man }\end{array}$ & $\begin{array}{c}\text { Vietnam } \\
\text { Philippines }\end{array}$ & $\begin{array}{c}1988 \\
1990\end{array}$ \\
\hline Africa & $\begin{array}{l}\text { 3. The Family } \\
\text { 4. The Beginning and } \\
\text { the End }\end{array}$ & $\begin{array}{c}\text { Emecheta } \\
\text { Mahfouz }\end{array}$ & $\begin{array}{c}\text { Woman } \\
\text { Man }\end{array}$ & $\begin{array}{c}\text { Nigeria } \\
\text { Egypt }\end{array}$ & $\begin{array}{c}1990 \\
1949\end{array}$ \\
\hline $\begin{array}{l}\text { Latin } \\
\text { America }\end{array}$ & $\begin{array}{l}\text { 5. Like Water for } \\
\text { Chocolate } \\
\text { 6. One Hundred Years } \\
\text { of Solitude }\end{array}$ & $\begin{array}{c}\text { Esquivel } \\
\text { Garcia } \\
\text { Marquez }\end{array}$ & Woman & Mexico & 1989 \\
Colombia & 1967 \\
\hline
\end{tabular}

Phase IV- Presenting the Expanded Sociological Analysis (ESA) of each Novel

In the presentation of data, the researcher adopted the following format: (1) analysis of the novel using the Expanded Sociological Analysis and (2) comparative analysis of the theme and concept of family in the novel, pointing out the commonalities and differences. Each format is discussed below.

\section{Analysis of the Novel}

The theme and concept of family were identified in this portion of the research. However, the study was limited to a sociological interpretation, as expounded by Kennedy and Gioia (2003). In the presentation of the analysis of the novel, the ESA focused on the cultural, economic and political aspects contained therein. The three (3) aspects were presented in the given order. The interpretations were guided by Marxist Literary Criticisms relative to ferreting out the concept of family.

\section{Comparative Analysis of the Novel}

After identifying the theme and concept, as presented in the analysis of the novel, the study compared and contrasted the commonalities and differences inherent in the works under study. Since there were six (6) countries represented in this research, the theme and concept identified in the novels readily revealed their novelists' thematic treatment.

\section{Significant Findings and Conclusions}

After analyzing the novels using the sociological framework as the basis for the discussion of the concept of family and the Expanded Sociological Analysis (ESA) in exploring the cultural, political and economic aspects supported by Marxist Literary Critics, this study presents the following salient findings: 
1. Reflected in the selected novels under study are the attenuating factors that affect the family disintegration/dysfunction.

\subsection{The Beginning and the End}

1.1.1. Differing values of family members cause family disintegration (e.g. augmenting family income, social acceptance, social mobility via education, etc.).

1.1.2. The family's struggle for economic survival adversely affects the members' dream to have education and engage in other family activities.

1.1.3. To improve the conditions of the family, the characters in the novel desire for social reform (giving employment for the masses, changing the political system, redefining Egyptian value system, etc.).

1.1.4. Politics rears its ugly head in love, work and the home (e.g. nepotism and influence peddling, marriage for convenience, setting aside family welfare for personal profit/ aggrandizement, etc.).

\subsection{One Hundred Years of Solitude}

1.2.1. Economic exploitation of the Latin American countries, Columbia in particular, as reflected in the establishment of the banana plantation, hence, Macondo becomes a microcosm of Latin American under Western imperialism.

1.2.2. Because of war and civil strife, political faction exists (e.g. Macondo is divided into the Conservatives and the Liberals) as well as divides the once cohesive family.

1.2.3. Influences of technology see the adoption of modern ways of farming and flourishing of other infrastructure developments (e.g. building of railroad, keeping pace with progress though in reality, they suffer economically and physically, but above all, spiritually.

1.2.4. The collective memory of the Columbians on their national history which is obliterated by the dominating political power has to be revived to regain their national pride (Marquez stresses the witnessing of the dumping of the dead plantation workers into the sea- a monumental history ignored by education and the government itself).

1.2.5. Family violence in form of incest, as practiced in the succeeding generations, causes not only the downfall, but also the total annihilation of the Buendias. 


\subsection{Paradise of the Blind}

1.3.1. Hypocrisy of the elites and the cadres in the Vietnamese society contribute to the sufferings of the vast majority. In other words, leaders who belong to the upper class are the only ones living in paradise. In fact, they are blind for not seeing and ignoring the real condition of the Vietnamese and the nation because they just confine themselves into their territories or comfort zones.

1.3.2. The corruption (e.g. bribery, abuse of power, deterioration of traditional culture, etc.) of the officials during the Vietnam post-civil war pushes the citizens of the country to the world of poverty.

1.3.3. The clash of traditional Vietnamese culture with emerging value system affects family relationship among members in decision-making, in disposing of family properties, even in attaining education for enlightenment, self-improvement and human dignity.

1.3.4. The civil war exacerbates poverty, peace and order, and migration, if not the separation of families.

\subsection{Like Water for Chocolate}

1.4.1. Women can continuously fight for their personal freedoms and individualities (e.g. Tita's personal triumph over Mama Elena's repression of her freedom and individuality).

1.4.2. Family tradition expects the youngest daughter to remain single to take good care of the aging, decrepit mother.

1.4.3. As upheld by tradition, the Mexican mother can lord it over her children's life and love (e.g. Mama Elena's matriarchal dictatorship over her children has affected the peace and harmony in the De La Garza ranch).

1.4.4. By extension, the use of manipulation, deception and deprivation by the matriarchal ruler to control the ranch has tremendously affected the relationship between and amongst her children.

\subsection{The Family}

1.5.1. The parents' abandonment of the family and their social roles have affected the personality of the children (e.g. Gwendolen actually suffered from what Victor Hugo's terms as a "dwarfed childhood".

1.5.2. Physical maltreatment and sexual abuse experienced by the protagonist (Gwendolen) from her parents (Winston and Sonia) and family friend (Uncle Johnny) virtually affect her attitude towards life. 
1.5.3. Economic Deprivation forces the Jamaican family to migrate.

\subsection{Mass}

1.6.1. The educated member of the society (Antonio) and the unlettered (Emy) defy family tradition in their incestuous relationship.

1.6.2. Loss of patriarchal identity (Antonio's) has immeasurably affected the succeeding generation (Pepe, his son).

1.6.3. The uninitiated thrown into the harsh life in Tondo confronts the problem of economic survival. To do so, the anti-hero (Pepe) earns a living by first experiencing the seamy side of the city, by becoming a literary editor and by serving as an acolyte.

1.6.4. Active involvement in the "brotherhood" - an alternative political group which openly supports its members promotes unity among varying social classes (e.g. Pepe immerses himself in the "brotherhood").

2. On the other hand, reflected in only one novel under study One Hundred Years of Solitude are these factors that militate somehow against the Buendia family before its eventual downfall:

2.1. The succeeding generations realize the unfinished modernization plans of the older ones (When Jose Arcadio Buendia starts to build Macondo, his dream of seeing this place progressive makes him engage in experimenting new things to benefit the village, but in vain, eventually his grandchildren make the modernization possible).

2.2. Ursula Iguaran Buendia, on the other hand, helps her husband by engaging in a small candy business and by gradually making it big. Her hard work and determination to succeed make the Buendias one of the wealthiest families in Macondo.

2.3. Jose Arcadio Buendia never dreams nor imagine seeing his Macondo destroyed or ruined, but his son Aurelio leads a civil war that lasts for twenty-one (21) years and ends only when he surrenders. While Aurelio fights, Jose Arcadio assigned to take charge of Macondo, turns out to be a ruthless dictator. Comparably, the Buendias' success and downfall affect Macondo's rise and fall.

3. The analyses of the six (6) selected novels from the emerging countries revealed the following concepts of family:

3.1. To protect the image of the family, the Egyptian parents (Kamel Efendi and Samira) portray and exercise the patriarchal matriarchal egalitarian rule over their children in The Beginning and the End, as 
the Columbian parents (Jose Arcadio Buendia and Ursula Iguaran Buendia) in One Hundred Years of Solitude do. However, the Vietnamese mother imposes the matriarchal rule in the Paradise of the Blind and the heroines (Mama Elena) in Like Water for Chocolate, and (Emy) in Mass. By contrast, the Jamaican father (Winston) in The Family solely over practices the patriarchal rule.

3.2. A Close Mini-Society where all the members of the family try to live together in times of happiness and sadness is apparent in Mahfouz's and Sionil Jose's novels.

3.3. One very important concept of family revealed in the mother's authority figure is seen in Mahfouz's novel (in the absence of Kamel Efendi) and in Thu Huong's as well as in Esquivel's work, including Sionil Jose's strong woman character.

3.4. Clearly seen is the multitude of social bonds based on consanguinity than on household among family members, be it in the novels of Mahfouz, Garcia Marquez, Thu Huong, Esquivel, Emecheta, and Sionil Jose.

3.5. As regards the social concept of family where every member lives together and does things together like solving problems and contributing to a peaceful environment, stands out very clearly in the works of the men and women novelists under study.

3.6. Lastly, the voluntary association concept that is, spouses can leave, children have outside resources to rely on if they perceive the family crumbling, is markedly present in Emecheta's The Family.

4. The following are the emerging concepts of family ferreted out from the novels under study:

4.1. The Martyrdom of the Mother for the Family. This is voluntarily shown by the Egyptian Samira to her children and family, the Columbian matriarch Ursula Iguaran Buendia to the entire clan, the Vietnamese elder sister Que to her brother Chinh, and the Filipino mother Emy to her son Pepe.

4.2. The Sacrifice of the Sister for the Protection of the Brother's Honor.

4.3. For instance, in Mahfouz's novel, Nefisa asks her brother Hassanein not to kill her and instead allow her to end her life to save him from imprisonment.

4.4. The Forgiving and Compassionate Character of the Daughter to her Parents for protecting the covert issues in Emecheta's. Despite her traumatic experiences with her father, and grandmother and her mother's negligence, the heroine Gwendolen chooses to be a forgiving and compassionate person for her family to remain intact.

5. Comparably and contrastingly, these concepts on family from both men and women writers: 
5.1. Apparently, all writers under study have common concepts of family, as reflected in their novels to indicate that though the novels were written by different writers from different periods, climes, races, creeds, and countries of origin, the universal themes and concepts of family hold the same and elsewhere.

5.2. However, the foci of the men and women writers vary. A closer look into the concepts presented reveals that both Mahfouz and Garcia Marquez focus on the patriarchal matriarchal concept in The Beginning and the End and One Hundred Years of Solitude. Unexpectedly, Sionil Jose highlights the matriarchal concept in Mass, as represented by his mother and his Aunt Bettina who strengthen the idea of high reverence and regard for women.

5.3. Notably, the women writers - Emecheta, Esquivel and Thu Huong present several family concepts based on consanguinity than on household or the so-called multitude of social bonds. Emecheta, by contrast, eschews the idea that the women writers would highlight women empowerment in their respective novels, in that she leans more heading on a patriarchal stance than that of a matriarchal.

5.4. Both the men and women novelists regard the multitude of social bonds as the predominating and major concept of family.

5.5. Each of the given concepts drawn from the novels strongly indicates that the universal concept of family varies through its specific subconcepts which are reflective of the conditions obtaining in novels from the emerging countries. With this premise, Asian, African or Latin American novels in stressing the concept of family unite and set a common, yet universal ground of highlighting the family as the basic unit of a society.

6. The novels under study, which focus on the concept of family, are manifestations of literature reflecting society. The novels succeed then in presenting in details the parts of a social reality that creates a total picture of the novels, as vehicles in framing out the conditions of the family (e.g. Poverty causes the rise and fall of the family particularly in the novels The Beginning and the End, The Family, Mass, and Paradise of the Blind).

7. In the process of analyzing, critiquing and interpreting the concept of family in the selected novels under study, Marxist Literary Criticism encompasses all components of social reality from the relationships of the members of family to the effects of some forces upon family survival such as cultural and economic status, war, prejudice, shifting values, change of government, and technological influences, etc. These and other more have also been emphasized by Marx in his view which he describes as the architectural metaphor: the "superstructure" (ideology and politics) rests upon the "base" (socio-economic relations). Marx further highlights the relations of exploitation and domination which govern the social and economic order of a particular phase of human history will in some sense determine the whole cultural life of the society. 
8. Observably, in the selected novels of emerging countries, the pattern of incestuous affair/practice exists, as brought about by the multitude of social bonds, the social concept of family where the members live together, a close mini-society concept of family, and other socio-cultural, economic and political factors.

9. In determining the concept of family along a sociological perspective, the models of Marxism such as Lukacs' The Reflection Model, Lucien Goldmann's The Genetic Model and Epifanio San Juan's The Society and Critical Theory lend themselves well to the novels under study.

\section{Conclusion}

Based on the above findings, this paper presents the following conclusions: the most common/predominating concept of family in the selected novels from the emerging countries is the multitude of social bonds, though each novel which was written by a different writer from a different period, clime, race, creed, and country of origin, the cultural, economic and political aspects appear to the three (3) influencing sociological factors that relate well to the concept of family, as presented in the selected novels, indeed, the novels used in this study are manifestations of literature reflecting the social realities, in most cases, novels from the emerging countries focus on the theme of poverty and alleviation from it, much less on the ways to combat it for the people to have a decent, normal life. Marx in his theory of society, politics and economics called "dialectical criticism" emphasizes the goal of history to have a classless society in which all people would share their wealth equally. This means that poverty should not exist and that all people should live a decent and normal life, family violence - in form of incest, religious bigotry, rejection, sibling rivalry, even neglect or abandonment of children - is relatively commonplace in the emerging countries, singularly, Esquivel has explored the theme of subversive femininity (hegemony) in a masculine world in the Mexican society in the first two (2) decades of the $20^{\text {th }}$ century, and in the interpretation and analysis of the selected novels from the emerging countries, their setting and historical milieus impinge on the formation of the family ethos (e.g. the Role of Martial Law in Mass and the Effects of Vietnam War in the characters of Paradise of the Blind).

\section{References}

Blau P, Meyer M (1971). Bureaucracy in modern society. New York: Random House. Chandler D (2014) Semiotics for beginners: Intertextuality. Retrieved from goo.gl/uZ TO2i. [Accessed: 23 April 2017].

Johnson H (1971). The Structural-Functional Theory of Family and Kinship. Journal of Comparative Family Studies 2(2): 133-144.

Kennedy X, Gioia D (2003) Literature: An introduction to fiction, poetry, and drama. New York: Harper Collins. 
Korsch K (1923) Marxism and Philosophy. Retrieved from goo.gl/jekp5o. [Accessed: 13 April 2017]

Literary Criticism Primer: A Guide to the Critical Approaches to Literature (n.d.) (Draft). Baltimore County Public Schools, Secondary English Language Arts. Retrieved from goo.gl/P26A4b.

Krekula C (2002) The concept of family from the children's perspective (Unpublished doctoral dissertation). Brisbane, Australia.

Maramba A (1993) Philippine Contemporary Literature. Makati: Society of St. Paul.

Marshall M, Huff G (1986) Literature as a mirror of reality: The family in historical and sociological perspectives. The Family in Literature Volume I, Yale-New Haven Teachers Institute. Retrieved from goo.gl/ytcm $5 q$.

Nam CB (2004). The concept of the family: Demographic and genealogical perspective. Center for demography and population health, Florida State University, USA.

San Juan E (1990) Text context: Society and critical theory. Manila: Asian Social Institute Printing Press.

Selden R (1997) A reader's guide to contemporary literary theory. London: Prentice Hall/Harvester Wheatsheaf.

Schwartz S (2005). Model of universal human values. Retrieved from goo.gl/f8uOVS. [Accessed: 23 April 2017]

Walhout C, Ryken L (1991). Contemporary Literary Theory: A Christian Appraisal. Michigan: Eerdmans Pub. Co.

Webster R (1996) Studying literary theory: An introduction USA: Arnold Publishing Co.

Whyte M (1987) Is America well served by its family system? Journal of Family Issues 8(4): 471-476. 